\title{
RITUALS AND HABITUS IN THE ANCIENT WORLD. AN INTRODUCTION
}

Ritualisation IS THE MOST PROMINENT form of religious action in Mediterranean antiquity and beyond. In order to communicate with the divine (and thus constituting its reality and shape) certain gestures, sequences of actions and words are differentiated from ordinary, pragmatic action, ritualised and even "sacralised" - by individuals as well as smaller or larger groups. Such patterns of action are repeated or taken as a blueprint for modification and innovation. They are the field for the establishment or questioning of religious authority, they are the means to temporarily or permanently mark out spaces as special. They sacralise not only spaces, but also times and natural or artificial material things, animals and people - and are drawing on such sacralised elements to determine, and elaborate on, the status of an action.

Research on ancient rituals has taken many different directions. They have been seen as the continuation of pre-human patterns of action or inventions of cunning religious specialists. Fruitful analyses have inquired about the "meaning" of such rituals as described by and ascribed to different groups of participants or individual observers. Others have stressed the aesthetics and patterns and the non-verbal logic of such actions. They have been seen as the dramatisation of traditional narratives or prescribed norms, shared values and conceptions of time of place. Plausibly, they could be analysed as incorporating and affirming social hierarchies or as the results of the individual framing of situations.

This issue of ARYS will follow a very different path, combining questions of individual performance and cultural pattern, social and material constellations. Taking the instigation of recent theorising on ancient religion as "lived religion"1 on the

1. Waldner, Gordon and Spickermann, 2016; Albrecht et al., 2018; Rüpke, 2019; Gasparini et al., 2020. 
one hand and sociological "resonance theory"2 on the other as points of departure, the volume will ask how certain rituals contribute to the formation of specific relationships of their actors to their material or social environment and to their own self or the wider horizons of the world in its entirety, whether in the form of divine symbols, a spatial world (like "nature") or a temporal one ("history"). What are the mechanisms of the development, "teaching" or habitualising of specific relationships to one's Self, to other people, to the material world or encompassing concepts like the divine or nature? How do the different elements of rituals - repetition and individual performance, models and preferences expressed, the reproduction of daily habits or extraordinary ways of acting - work together in such processes? What is the role of rituals in shaping the disposition of those involved, regardless of in what role they are involved - as specialist, performer, participant or "mere" observer?

Contributions have been invited from all relevant disciplines like Ancient History, Classical Philology, Archaeology and History of Religion. We are very grateful for the many proposals and submissions and the labours of the journal's reviewers whose intensive critique helped to shape this issue and to improve its quality. Contributions were asked to engage with a specific type of ritual action, literary views of such ritualised action or material and architectural arrangements in certain cultural contexts or epochs throughout the ancient Mediterranean world. Engaging with the central research question of the volume authors needed to reflect their methodological approach and the possibilities and limitations of generalising their findings.

The volume is opened by a methodological article written by Jörg Rüpke, "Establishing Self-World Relations in Socio-Religious Practices. Looking at Roman Religious Communication". Starting from the concepts of religion as communication and resonance, his article analyses the details and varieties of religious communication in ancient Rome. On the basis of the pragmatic relationships and cognitive associations of such rituals, the article inquires into the self-world relations that were established in such performances. Anna-Katharina Rieger's article "The Spectrum of Religiousness, or What Makes an Object Religious. Habits, Patterned Evidence and Religious Meanings of Image-Objects in Pompeii" shares in this bottom-up methodology. Against the backdrop of the pervading presence of imagery, objects, and buildings that refer to deities, cult practices, or mythology she analyses rituals not as a well-organised set of prescribed sequences of gestures, but as "religion in the making" as reflected in and using the full breadth of material religion at Pompeii.

2. Scheuermann and Spickermann, 2016; Rosa, 2019. 
With Fayah Haussker's “Children's Supplication in Classical Athens. Religious Skills, Survival and Inferiority" we move into a series of case studies focusing on ancient Greek and Athens in particular. Reconstructing children's experience as supplicants from the full range of sources allows to contextualise their specific performance within the larger range of rituals. In difference to others, however, supplication presents the children and makes them experience their inferiority rather than acquiring ritual knowledge in an ongoing process of step by step introduction to the status of adult citizens. Ronald Blankenborg moves further back in time to Archaic Greece for his "The Rhythm of the Gods' Voice. The Suggestion of Divine Presence through Prosody", studying in depth the performance of the human-divine relation.

The following article also starts, in a way, with Athenian drama, but takes an explicit comparative approach by putting the Plautinian Rudens and Simone Weil's Venise Sauvée side by side. In "How to Write Religious Ritual into Theatre. Gérard Genette's Palimpsests Applied in Plautus' Rudens and Simone Weil's Venise Sauvée", Latinist Blaž Ploj and theologian and literary scholar Thomas Sojer transform Gérard Genette's concept of hypertext into a tool for ritual studies and introduce the concept of "hyper-performativity". The idea of performances referring to other performances and thus producing meaning allows to look for building blocks of other rituals in the theatrical performance or guided imagination of dramatic rituals, thus intensifying the emotional and cognitive impact of the performance directly witnessed.

Literary texts and reading experiences are also at the basis of Enno Friedrich's and Ursula Gärtner's analysis of late ancient poetry in $6^{\text {th }}$ cent. CE Gaul and its use of the figure of Martin of Tours in "The Many Martins of Venantius Fortunatus. Venantius Fortunatus' Martin-Poems as Instances of Individual Appropriation and Literary Offers of Ritual-Like Experience". Here, the focus is on the cross-media relation of ritual experiences in the veneration of the Saint to the different settings of 1) the original listening act to the first performance or 2) the later reading of the text in a collection of poems approached with tools from Lived Ancient Religion as well as Resonance theory.

The next pair of articles takes space even more into account. Ben S. Cassell thematises "The Thesean Ritual Landscape. Appropriation, Identity and Athenian Collective Memories". Moving back in time to $5^{\text {th }}$ cent. BCE Athens, the article analyses the various forms in which the narratives about Theseus are performed and repeated in a calendar pattern throughout the year. The experiences of this narrative in contexts that construe linear as well as cyclical temporalities helps to understand the construction of Athenians memories and identities in much more nuanced form. Particular experiences of spatiality and temporality on the different tiers of ritual performance and literary mediation are the subject of Maria Hirt's analysis. "Rural Rites in Ovid's Fasti" show how the tension between imagined ritual performances in 
an idealised rural setting and the urban experience of the metropolis produce specific effects in the political setting of Augustan Rome.

Annika Krahn adds a further facet by turning to a very different literary, namely Jewish, tradition of the Greco-Roman world and its developing accounts of ritual practices, namely the narratives of healing rituals in biblical texts. "Magischer Krankenheiler und Sohn Gottes. Die jesuanische Krankenheilung als magisches Ritual und das Phänomen der De-Ritualisierung in der redaktionellen Überlieferung der Evangelien" focuses on intertextual processes against the backdrop of ritual practices and their prominent role in shaping the figure of Christ in the biographical narratives of the gospels.

In the last contribution, Ramón Soneira Martínez turns to conceptual questions about the basis of religious rituals and the mindset of ritual agents in antiquity. "The Nóбoৎ of Declaring that Gods Do Not Exist in Plato's Laws. Isolated Cases or Groups of "A $\theta \varepsilon o$ ??" makes us aware that the notion of "unbelief" should not be used to construe categorial differences between contemporary and ancient ritual practices, but opens up a more nuanced view of religious agency in the classical Mediterranean world.

We are grateful to the many discussions with and inspirations by the junior and senior researchers of the joint International Graduate School "Resonant Self-World Relations in Ancient and Modern Socio-Religious Practices" of the Universities of Graz (Austria) and Erfurt (Germany) and its support by the FWF Austrian Science Fund and the DFG German Science Foundation. We are indebted to the editorial board of ARYS for their critical review and final acceptance of the concept as much as the final group of articles. On their behalf, Valentino Gasparini was of invaluable help during the whole process, from the call for papers to the final revisions.

Elisabeth Begemann AnNa-Katharina Rieger JÖRG RÜPKE WOLFGANG SPICKERMANN KathaRina WaLDNER 


\section{BIBLIOGRAPHY}

Albrecht, J., Degelmann, C., Gasparini, V., Gordon, R.L., Petridou, G., Raja, R., Rüpke, J., Sippel, B., Urciuoli, E.R. and Weiss, L. (2018). Religion in the Making. The Lived Ancient Religion Approach. Religion, 48.4, pp. 568-593.

Gasparini, V., Patzelt, M., Raja, R., Rieger, A.-K., Rüpke, J. and Urciuoli, E. (eds.) (2020). Lived Religion in the Ancient Mediterranean World. Approaching Religious Transformations from Archaeology, History and Classics. Boston and Berlin: De Gruyter.

Rosa, H. (2019). Resonance. A Sociology of the Relationship to the World. Cambridge: Polity Press.

Rüpke, J. (2019). Lived Ancient Religion. Oxford Research Encyclopedia, Religion, DOI: 10.1093/acrefore/9780199340378.013.633.

Scheuermann, L. and Spickermann, W. (eds.) (2016). Religiöse Praktiken in der Antike: Individuum - Gesellschaft - Weltbeziehung. Graz: Universität Graz.

Waldner, K., Gordon, R. and Spickermann, W. (eds.) (2016). Burial Rituals, Ideas of Afterlife, and the Individual in the Hellenistic World and the Roman Empire. Stuttgart: Franz Steiner. 